\title{
Between Aesthetics and Politics: Socially Engaged Art on the Internet
}

\begin{abstract}
Winiecka Elżbieta, Between Aesthetics and Politics: Socially Engaged Art on the Internet. "Poznańskie Studia Slawistyczne" 17. Poznań 2019. Publishing House of the Poznań Society for the Advancement of the Arts and Sciences, Adam Mickiewicz University, pp. 303-319 . ISSN 2084-3011.

The author discusses the changes in the model of democracy that have occurred since the Internet began. The hierarchical model of representative democracy is replaced on the Web by participatory democracy. On the example of Siksa and Bread Resolution (Rozdzielczość Chleba), the author shows up the transformations of the model of literary communication on the Internet. She also indicates ethic role engaged art takes in the contemporary society. Artists that produce socially engaged art do it in the name of those who do not exist in public space, those whose voice is not heard and who cannot defend themselves. Nevertheless, the author comes to the conclusion that the real democratic revolution can only take place outside the Web.
\end{abstract}

KEYwords: socially engaged art; participatory art; democracy; literature on the Internet; Siksa; Bread Resolution (poetic group)

We are living in the era of the Internet. There is no exaggeration in this term coined by the Spanish sociologist and communication expert, Manuel Castells. He has analyzed the power of technology on the basis of large social movements from 2011-2012 in his book titled Networks of Outrage and Hope (Castells, 2012). He described their momentum and effectiveness what was possible thanks to the social media.

The hierarchical model of representative democracy (i.e. type of traditional indirect democracy in Western countries founded on the rule of a group of people chosen in the election) is replaced on the Web by participatory democracy (direct, individual citizens' participation in political decisions that affect their lives), which has a horizontal structure; it also ignores the intermediation of state institutions in organizing activities, and it 
rejects any form of leadership. Citizens, wary of politicians' actions, want to have a real influence on the decisions taken on their behalf. However, because politicians are unwilling to broaden public participation in the exercise of power, the impact of grassroots social movements on reforms of the political system is mainly indirect. Castells draws attention to different ways in which social activity can influence political reality: "movements [on the web] affect people's minds" (Castells, 2013, 226). They raise citizens' awareness of the discussed issues along with their civic impact on the shape of politics and quality of public life.

And this is where the political dimension of social movements and the political nature of artistic activities converge. Here begins the real story about the involvement of online contemporary art and literature in real life and in social problems, as well as about the aesthetic actions taken for the sake of political change.

The Internet has altered the status of art, its creators and the public. Its utopian project is the 2.0 culture model, a symbolic communication space available to everyone, co-created by the whole. Thanks to the cheap and easy-to-use digital tools and open distribution channel, such as the Internet, both professionals and amateurs participate in creating content. For people born in the 1980s and later, this new model of culture, which has developed beyond the institutional and hierarchical structures of traditional, i.e. analogue culture, constitutes a natural environment. The media interactivity, multimedia and convergence of media, as well as the possibility of using open access resources, are natural conditions for their activity, which is characterized by creativity and courage in presenting themselves and their achievements. The primary artistic form of expression is the remix that is, the art of capturing and processing ready-made songs. For young artists, the idea of the interconnected, free culture is not a new utopia, but integral part of their identity that has been shaping their sensitivity and way of thinking.

Beginning in the 1990s, the participatory art, which engages viewers in the creative process making them co-authors, observers of the work which is incomplete without their interaction ${ }^{1}$, has been developing with the help of the Internet. It often takes a hybrid form that is, it includes

${ }^{1} \mathrm{~A}$ comprehensive discussion on the participatory art and its variants is provided by Eliza Urwanowicz-Rojecka (2015). 
online activities as well as those that take place in urban space or in galleries. Its aim is to mobilize the audience and to include them in efforts aimed at changing the situation of different social groups that have been wronged by the current system and legal norms. Finally, the participatory art can also expose injustices, since it makes visible what has earlier been invisible, and gives voice to people who do not have a voice.

This is how Jacques Rancière's concept of democracy comes to fruition. Rancière reminds us that the word 'democracy' has been used by its adversaries, who mocked the fact that the "demos rule" consists in exercising power by those who have no title to exercise it. "Demos include those who do not count, who have no voice and therefore cannot be heard" (Rancière, 2008, 23). That's why democracy, explains Rancière, "is the very establishment of policy, the establishment of its subject and form of relationship" (Rancière, 2008, 23). Politics would be an exception to the normal state of affairs, according to which people submit to those who have the title to exercise power.

To deny people the right to speak is tantamount to pushing them off the public stage, depriving them of their subjectivity. This is the case, for example, with women, sexual minorities, nationalities, denominations, victims of domestic violence, and people with disabilities. Their voices are usually inaudible, treated as meaningless gibberish. This is how social groups that are for various reasons problematic are relegated to the space of absence, emptiness, non-existence, because being a political subject is predicated on being audible and visible.

This is why "The essence of politics is discord" (Rancière, 2008, 31). It serves to expose what is invisible and what escapes rational discourse. Anyone who belongs to a world overlooked by others must "show a world in which his arguments are just arguments" (Rancière, 2008, 31). A woman who demands equal rights in a patriarchal society, a person in a wheelchair talking about architectural barriers that prevent her from leaving the house - they make their private matters public, they also raise them to the rank of public problems requiring solutions.

Such political activity introduces a new way of seeing and understanding what is visible, audible and deserving of attention. Art is a natural ally of political activity because it reveals the invisible mechanisms of social injustice and indifference, exposes the various forms of exploitation, slavery, 
abuse of power, bringing to light the languages which reinforce stereotypes and promote hate, and finally it simply demands respect for every subject. What is more, this political dimension becomes a part of such a defined art, which is why socially engaged art is political art.

The discussed art sets for itself one main goal namely, to exert influence not so much on reality as on public awareness. This is, therefore, a type of indirect influence on the social situation, because only people who have been stimulated in such a manner are able to take action and make decisions to change the social and political order. Claire Bishop draws attention to this:

The desire to activate the audience in participatory art is at the same time a drive to emancipate it from a state of alienation induced by the dominant ideological order by this consumer capitalism, totalitarian socialism, or military dictatorship (Bishop, $2013,27) .^{2}$

Artists engaged in the participatory art are interested in the renewal of their community, in engaging the public to take part in activities initiated by the artists, and in developing a sense of responsibility for themselves and others.

Polish artists involved in this type of art are predominantly young. They are the ones who actualize a completely new model of an artist, one who not only uses his or her artistic activity as a tool for intervention but also makes use of the new possibilities afforded by the Internet in order to build a community of like-minded individuals. A good example of such an artist who is very engaged in feminist activities is the Polish poet and performer, Alex Freiheit (in German: freedom). She co-founded the punk duet Siksa, which refers to the music of the 1980s in both stylistics and political engagement. She uses a strategy of provocation and scandal on the stage. Her stage incarnation carries bright make-up and provokes the male part of the audience. In this way, she destroys the stereotypical image of a well-behaved, polite girl. She wants her behavior to embolden other women to change their attitude. During her performances, she

${ }^{2}$ This is the concluding fragment (Conclusion) from Bishop's Artificial Hells (2012, 275). 
exceeds aesthetic norms. The opinions of artistic critics are not important to her.

Siksa performs poetic slams and concerts in small clubs, squats, art galleries both in Poland and abroad (among others in Lithuania, Belarus, in the Czech Republic, Germany and England). Parts of her performances have been documented and are available online. All her performances are accompanied by harsh music during which she screams out her texts scandalous, vulgar and aggressive, but also bitter and very critical as for the cultural and social realities connected with the violent treatment of women, sanctioned by the state and legitimized by tradition. Her onstage appearance is part of an artistic plan to, firstly, draw attention to the problem of sexism and patriarchal culture and, secondly, to incite a rebellion against this state of affairs and, thirdly, to bring about a change in the system. This is a manifestation of direct democracy which is emotional and engaging. The artist herself attempts to change the situation of women and supports others to do the same. On the websites where her work is made available, one can read a short declaration:

SIKSA encourages girls to dump weaker boys and encourages boys to be cool and not BUC or overly critical and so on. Herstory of SIKSA is part of the history of this country and the world and the final end of history. ${ }^{3}$

In Patriotyzm jutra (Patriotism of Tomorrow), included in her album of the same title, she screams out:

I'm an enemy

My name is Siksa

For million siks [siksas???] do I love and suffer agony. ${ }^{4}$

Derived from Yiddish, the word 'shikse', 'shikses' is always a pejorative, often offensive, term for girls. In the less radical version, it is used as a dismissive, contemptuous term for a young woman. Siksa, in all her musical and performative activities, identifies herself with the victims of patriarchal protectionism. She involves her own self, including her body

${ }^{3}$ https://siksa.bandcamp.com/album/poljestrowe-cierwo; https://siksa.bandcamp.com/ album/patriotyzm-jutra-split-w-marsza-ek. 2.02.2019.

${ }^{4}$ https://siksa.bandcamp.com/album/patriotyzm-jutra-split-w-marsza-ek. 2.03.2019. 
and biography, into the space of artistic activities. It's also worth considering what the artist says about the social effects of her artistic activities:

It seems to me that what is happening after our concerts is a performance which continues after the concert ends. It is interesting to watch it develop (Smoleń, 2017).

The performance plays the role of a kind of intermediary between what the artist wants to express and what the viewer feels. It is the "third member" of which Rancière writes that "The same thing that binds them must also separate them" (Rancière, 2007, 317).

Because many of Siksa's one-off, performative acts are recorded and shared online, viewers watching these recordings find themselves in an ambiguous position. Due to intermediation, the boundary between participation and the spectacle is blurred. In this case, however, this spectacular, mediating role of the Internet strengthens the artistry and creativity of Siksa's performances, rescuing her aesthetic values from being absorbed by purely political considerations.

Siksa takes a radical stance not only against the social and cultural stereotypes, but most of all against the degradation of women and the very real acts of violence perpetrated against women.

The work cited earlier mixes fragments of authentic recordings of domestic violence perpetrated by a politician abusing his wife (already known to the public from the media), sexist speeches of a Polish MEP in the European Parliament, as well as statements by television guests and other materials illustrating the real, often extremely dramatic situation of women in Poland. All this is presented to the accompaniment of harsh, punk music, enriched with electronic acoustic effects.

The bitter context of Siksa's artistic work is Polish literature and culture with their cult of courageous and heroic men and meek and submissive women - the idealized "Polish Mothers". Adam Mickiewicz and Marcin Świetlicki - two of Poland's great poets - become in Siksa's work exemplars of that type of thinking. From Siksa's perspective, it is their poetry that has contributed to reinforcing the patriarchal cultural system, one which poets even today gladly perpetuate. That is why Siksa often dedicates her subversive performances to them, consistently making the language of male poetry the subject of her criticism, and the sarcastic allusions to these poets serve as an instrument of cultural and social critique: 


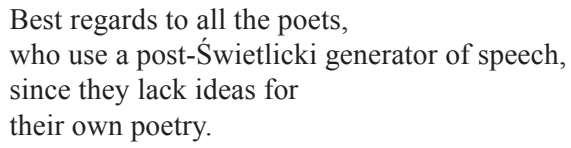

If we are to agree with Claire Bishop's statement that the real democracy should be a relation of opositions, as otherwise it becomes an imposed consensus (Bishop, 2006), then the strategy of provocation and scandal, intensifying the clashing viewpoints and convictions, becomes the most effective means by which conflicts and mechanisms of social exclusion are brought to light. Socially engaged art thus defined today has as its goal to incite social change. By purposely employing the aesthetics of kitsch, exaggeration, screams, vulgarity, this art evokes discomfort in the audience. And by drawing attention to the marginalized or dismissed social problems, it becomes socially useful, performative not only in the artistic sense but also politically: it brings about great social transformations. Incidentally, it can be seen that this way art assumes the protective role of the state, taking the side of the weak, disadvantaged, and those neglected by the system or even excluded from it. It is in the area of engaged art - and not in the space of public debate - that a redefinition of such concepts as community, identity, responsibility, and civic attitude is possible today.

Siksa's art first takes place on the stage and only then it is reinforced through its existence on the Internet. From the point of view of literary studies, the obversed situation seems more interesting - that is, when the Internet contributes to innovations in the field of literature. In Poland, the Internet has been developing for over the quarter of the century, entailing during this period phenomena related to a new virtual space of literary communication.

An alternative space of literature, one which takes advantage of the Internet as a medium, somewhat covertly develops parallel to traditional and dominant model of literary life. At around the turn of the twenty-first century, its subversive power became an inspiration to create a new utopia. The source of this utopia is the Internet construed as a model of a new democracy and digital space seen as a nonplace brought to life, in which the real life, as well as artistic life, takes place in the here and now. New digital works are created and the old works, previously available in print, are now 
digitized and find their way online, where they can be accessed practically without any limits. This vision of a fully available, free culture has become an inspiration for artists, who appreciate the revolutionary potential of new technology by treating it as an opportunity to renew literature. For the first time, this kind of belief was articulated in 2002 by a group of young Warsaw poets who formulated their Neolinguistic Manifesto v.1.1. In the program's manifesto, jokingly stylized as a futuristic one-day trip, they announced the beginning of a new era in which the Internet, like the Machine from the beginning of the twentieth century, will become the main engine of transforming reality. However, because this manifesto remained largely an abstract project, not reflected in reality - the Internet was still not very accessible at the beginning of the twenty-first century - from today's perspective it can be considered a joke or a prophetic vision rather than an aesthetic program that the poets succeeded to realize.

A symbolic breakthrough, on the scale of the interwar avant-garde movements, took place almost ten years later. Its initiators were Leszek Onak, who calls himself "the creator of literary algorithms" and Lukasz Podgórni - "manufacturer of designs, apps and unidentified literary objects". Along with Piotr Puldzian Płócienniczak, Tomasz Misiak and Tomasz Pułka, they established in 2011 The Bread Resolution Publishing $\mathrm{Hub}-\mathrm{a}$ publishing and artistic collective as well as a patainstitution. According to its founders, this was supposed to be the beginning of a new stage of culture: open-access, free and democratic. A hub - automat, which connects many devises on a computer network, a kind of communication junction, was to become the command center of a new, digitized culture. The first part of the name, Bread Resolution, also clearly refers to the digital character of the endeavor as well as to the revolutionary activity not unlike the miracle of Jesus dividing bread. The iconoclastic overtone of the name drew attention to the remarkable role of technology, which allowed the texts to be multiplied ad infinitum, thus making culture accessible to the general public.

The guiding principles behind Bread Resolution question capitalist logic in which economic rules reign supreme and in which producers of culture also become products, sold to generate profit. In the Bread Resolution Manifesto, formulated in December of 2011, one could recognize a familiar militant rhetoric of the futurists: 
Paper is coming to an end and there is no point putting in another roll! Let us digitize the entrails of libraries and burn them in order to use their warmth to lay the eggs of new procedures and digital mutants feeding on code

Corporations and e-publishers hoping to imprison culture in a $\mathrm{DRM}^{5}$ gilded cage are advised to kindly: Fuck off!

Greed will lead you to bankruptcy - using our keygen we will destroy all security measures and mental barriers, and then start drawing from culture, in whole terabites, whaterever we need! Try to arrest the wireless word! ${ }^{6}$

The artistic conception held by Bread Resolution extends even further. It develops the perspective of the ever-increasing involvement of technology in the fabric of social and literary life and its integration in the human organism. Written the quarter of the century after Donna Haraway's Cyborg Manifesto (Haraway, 1985), the Manfiesto is no longer shocking in its radicalism; however, it does sound bold as a project endeavoring to transfer artistic activity from the real world to the Internet.

There are no authors and readers, only producers and users. There are no works - only programs, objects, pseudocodes and web performances: It is high time we make use of the potential of chats, social media and videophones. They will be our next literary cafés. We don't talk about subjects, but about avatars. Not a presented world, but a simulation!

The Bread Resolution Manifesto, ecstatically foretelling the new cultural revolution, had the characteristics of being the last of the avant-garde utopias. It can be regarded as a kind of pastiche, playing utopia. The artists were aware of the end of all great projects. Hence the self-ironic attitude that accompanied their actions.

From a sceptic, post-utopian perspective of postmodernism, it could be considered a naive avant-garde (or an attempt to resurrection the avant-garde) because its artistic activity imposes itself on social space with the hope of reorganizing the latter. Their artistic activity, based on program code, uses the aesthetics of glitches, disruptions, generators of poetry and

${ }^{5} \mathrm{DRM}$ - from Eng. digital rights management, a security system concealing content to protect data from being used against the wishes of the publisher.

${ }^{6}$ All citations from: Manifest Rozdzielczości Chleba, https://rozdzielchleb.pl/manifest/. 5.05 .2018 . 
remixes, which has made their work less approachable, thus creating an even greater chasm between the audience and art. Simultaneously, a distinct tone of social criticism accompanied these efforts, criticism directed towards institutionalized and marketed culture. Cybernetic activists were interested in liberating art (mostly literary) from the control of institutions and in developing an egalitarian form of art by broadening access to it. This plan was, however, unrealistic mostly because the proposals put forth by Bread Resolution had and still have a remarkably hermetic quality. These proposals are located in an artistic niche not only because they have emerged outside mainstream culture and beyond the Web but also because they demand from the audience a degree of competence in literature and art, and, most importantly, critical, reflexive approach to it. For this very reason, they remain a rather unknown phenomenon.

Employing the strategy of provocation, which oscillates on the border of blasphemy, scatology and vulgarity, the artists/programmers in subsequent online projects demonstrated a disregard for culture and the values related to the areas of sacrum and cultural taboos. They tried in this way to cast some light on the anachronism and injustice of the traditional cultural model, in which access to its resources are in the hands of the chosen, in which authors' rights are protected by the anachronistic regulations originating from the era of print media, and in which this anachronistic and unreliable cult for individualism and originality still persists.

The Bread Resolution Publishing Hub has set a goal for itself - to alter Polish culture. Recognizing the obsolete values in its traditional, hierarchical model, based on the cult for individual skills, one-directional communication, and, most importantly, on the printed word, it began to introduce to the Web new rules of cultural life. The artists created a webpage, which was the only location of the Hub and also, as behooves an organization meant to propagate culture, a digital magazine under the metatextual title Nośnik (Medium). The cover informs us that the place of publishing is the Internet, the price $0 \mathrm{zl}$, and the circulation is $\infty$ (infinity). The three characteristics of these rules are the following: location on the Internet, and free, unlimited access were to be the beginning of a great revolution. "A miracle is not needed to multiply bread - it is enough to download a file!" - is one of the mottos of the Hub, which directly refers to the evangelical miracle of dividing bread as the prototype of free culture. By 
playfully and self-ironically invoking the evangelist model, the creators of the Publishing Hub took as one of their main operating principles to give free access to all their work. The conviction that free access will contribute to increasing the popularity of poetry and other cultural products was an expression of the optimistic, though unsubstantiated, belief that egalitarianism would in some unusual way reinforce the readership of niche works. E-publishing was strengthened by live performances and concerts; these ventures aimed primarily at addressing the issue of copyright and phenomenon of collectivism, which appeared as an alternative to the institution of an individual author.

When it became clear that the revolution is not coming, and the world continued on its previous path, while the cyberartists remained outside institutionalized culture, the first avant-guard stage of Bread Resolution came to a close.

In 2015 the founders of Publishing Hub published another program. This time it was the Cyberbum Metamanifesto - a digital entry meant to be a kind of reckoning with the era of the Internet, admission of failure of their earlier declared ideas and, at the same time, the inauguration of a new, critical stage of the collective's activity. From that point on, the group became explicitly socially engaged. These cyberartists took as their subject of criticism the unjust social system, which further increases social inequality in accordance with capitalist rules of the market. These rules tend to promote productivity in the service sector, further relegating independent culture into an even more obscure niche.

Metamanifesto is a kind of remix of the language of economics and the market as well as the jargon of programmers, along with the theme of culture and creativity, and also linguistic manifestations of the moral and aesthetic decay of the authors. This collapse was caused, as they suggest, by the mechanisms of power represented by the cultural institutions that they fought and. on the other hand, by the effects of digital technology. They have become its involuntary victims and they give voice to this in their new program. Cyberbum Metamanifesto presented the situation of authors who admit that their earlier optimism was excessive. The metacritical dimension of their performances is both self-thematic and self-ironic: the artists mockingly refer to their naive plans formulated four years earlier, which aimed to expose the hidden mechanisms of public institutions' 
power and dehumanizing dimension of computers and the Internet. The subject matter of subsequent ventures was to present not only a critical view of consumerist, patriarchal pop culture, but also their own biographies. This ambiguous position of the members who present their biographies as cyberbums - victims of the system and their own naivety dovetails with the ZUSwave project, initiated in early 2015. It is run as a Facebook profile. टट्टीZ U S w a v e (it is no coincidence that the sign at the beginning of the name means stomach in Hindi). It has also become the guiding theme of one of the issues of "Medium" magazine ("nośnik"), thereby becoming the hallmark of the new aesthetics of Bread Resolution. Stark and kitschy, it draws on the simple graphic design of the 1990s. The aesthetics of simple collages saturated with nostalgia for this type of design is part of the vaporwave trend - a genre of music and graphic art created in 2011 by the Internet users. Similarly, it expresses the fascination with early digital culture (mainly the ' 80 s and '90s) as well as the then developed technology along with commercials and video games. These graphically simple, if inept, collages make use of bright colours, and refer to the ancient and oriental culture. As musical background, this aesthetics usually takes the form of primarily simple electronic music themes associated with early computer games. In the West, waporwave is an instrument of criticism and satirical representation of consumerism, mass culture and narcissism of the Internet users. Drawing inspiration from this, ZUSwave first becomes a critique of the pension insurance system seen as a tool for repression and stigmatization, and then the entire system of public institutions, capitalist model of economy and pop culture, which simplifies and trivializes every problem.

Cyberbum activities, strengthened by exhibitions, soon lost their momentum. Already in 2016, a new program appeared, defined by its creators as successivism. It coincided with the declared departure from patriarchalism of the Internet and the invitation for women to join the collective artistic activities. Today, the Bread Resolution Collective consists of Julia Girulska, Leszek Onak, Łukasz Podgórni, Piotr Puldzian Płucienniczak, Kinga Raab, Wojciech Stępień and Agnieszka Zgud.

Another idea for cultural contraband has resulted in one exhibition entitled Succession of Bread Resolution. The opening of the Bread Resolution Succession in Krakow lasted from March 22 to April 5. During the 
first evening, it took place in the urban space and in a club (an attic); the event was conceived as a parodic spectacle, combined with performative activities whose main object of attack was capitalism and its socio-cultural effects. Participants, like in a folk comedy dell'arte, took on caricatured roles of people who have made it in capitalism, combining improvisation with the exhibition of Bread Resolution. Anna Batko, who participated in the evening show, describes the atmosphere of the event by listing its main features: "Bad taste, a lot of nostalgia, dreams, aspirations, ostentation and simple advertising slogans" (Batko, 2018).

The exhibition lasted two weeks. As a result, cybernetic artists reached for classic means in their literary and publishing efforts: mocking and provoking in order to draw attention to the social effects of capitalism and allow the public to see through the distorting mirror of the happening. On October 31, 2018 Hub announced the end of its activities.

Claire Bishop called the contemporary interest in social life the "return to the social" (Bishop, 2012). She talks about the current intensification of socially engaged art in the context of a critique of the neoliberal system, individualism and commodification. This last phenomenon, in light of the Internet revolution, has acquired a new, yet unknown, dimension. In the times when information is the most valuable asset, it is us - as users of the Internet - who have become the product. Undoubtedly, we are certainly participants in a new stage of capitalist development. The artists, by undertaking artistic ventures at the junction of two spheres of contemporary life - on and off the Internet - have set a goal to draw attention to the multifarious consequences resulting from this situation. That is why they make their own biographies, bodies and real accomplishments not only the subjects but also the objects of artistic activity. Those on the Internet take place at the crossroads of creation and communication with the public.

However, the ease with which we use the Internet conceals a trap, since, on the one hand, it gives its users a sense of freedom and efficiency;

${ }^{7}$ Functioning under the eccentric name 'Primer for City Residents' (Elementarz dla mieszkańców miast). 
on the other hand, communication is once again subordinated to the rules of new technologies that turn its creators and the audience into a commodity, instead of the work of art. The audience is then used without its knowledge and consent. Let us once again refer to Bishop:

Arguably this is a story that runs in parallel with the rocky fate of democracy itself, a term to which participation has always been wedded: from a demand for acknowledgement, to representation, to the consensual consumption of one's own image - be this in a work of art, Facebook, Flickr, or reality TV (Bishop, 2012, 275).

The ease with which anyone can produce content and upload it for public viewing brings to mind associations with democratic activity. However, the democratic nature of the Internet is an illusion, as it would seem that only taking action in the public sphere - that is, offline - makes achieving real change at all possible. It must be remembered that social media sites described just five years ago by Manuel Castells as a space of autonomy, in which people communicate freely and remain "largely outside the control of governments and corporations that previously monopolized communication channels and made them the foundation of their power" (Castells, $2013,14)$ seem to be a thing of the past, if they had ever been anything more than an utopian dream.

In discussions about the future of social media, the word 'responsibility' appears more and more often. Since the algorithms make the initial selection of the content, giving the user the illusion that it is he or she who is to decide about everything, the responsibility for the quality and nature of public debate seems to rest with those who create algorithms, that is, the owners of websites and IT specialists responsible for the codes that create cybernetic space. However, if the algorithms and the people standing behind them are the cause of today's problems with democracy on the Internet, this would paradoxically be optimistic news. As Michał Kuźmiński noted in an article devoted to the cultural and political role of Facebook, in the end, "Democracy does not threaten the algorithm, but pride, greed, impurity of rules, jealousy, immoderate, anger and laziness" (Kuźmiński, 2018). This symbolic list of sins of the Internet users makes it clear that the fate of participatory democracy lies in their hands. Either they will give up critical thinking, alertness and caution, thus abandoning control over their own lives, or they will take ethical and political actions to improve 
the situation. Socially engaged art that is developing on the Web is often labeled post-Internet in order to emphasize its skepticism regarding the solutions offered by the new technology. In these altered conditions, it takes on the role which it had played earlier in physical social space - a conduit between the artist and society.

The question which Bread Resolution asks its audience can be formulated in the following way: is it possible to escape the logic of capitalism, to escape beyond the rules that rule the market? The members of the collective are perfectly aware that "Art is a market and there is no denying that" (Carnevale, Kelsey, 2007, 155), and, therefore, every emancipatory attempt made by art is condemned to failure. Nevertheless, it is important to maintain the game, to create the space of communication between artistic ventures and society in which it will be possible to surprise the audience with something which may change their viewpoint or way of thinking. To this end parodying the world of celebrities, the mocking use of pseudoexclusive signs of luxury, intended to symbolize the aspiration to being inscribed in the rules of the capitalist model of life, in which the measure of success is the material situation that determines its social position.

However, these are not signs of a naive belief that such subversive activities will allow their disposal. It is all about expanding the field of what is visible, bringing to light the invisible rules of conduct that guarantee "success".

Socially engaged art, as cultivated by Bread Resolution, not only wants to bring about change as to bring to light the problems connected with the conditions of contemporary artists, rank and file worker, small-time entrepreneur struggling with administrative restrictions. In this way, the art's field of influence pervades the social space, which becomes a place of democratic discussion and social (self-)reflection.

Only this way does the Internet have a chance to become a space of emancipation. In order to earn the name of a place where freedom is regained, it has to constantly question the principles according to which it operates: deconstruct them, parody them, negate them. This way anarchy becames a road to rescuing democracy.

The collective art by Siksa and Bread Resolution, discussed here summarily, exemplifies a broader phenomenon which can be called the culture of change, prompted by the appearance and development of the Internet. 
In giving voice to victims of violence, Siksa, who declares herself as one of a million siksas deprived of subjectivity and the right to be heard, makes this voice audible. Siksa brings to light what the system renders invisible, thus making her work political, and by extension democratic.

Bread Resolution, on the other hand, draws attention to the problems connected with unequal access to culture in the capitalist system as well as to the situation of social groups that are invisible to institutions representing the nation, since they do not meet the criteria according to which a citizen is defined today. It is at this point that we can formulate the main message of the long-term project developed by Bread Resolution: it is to address in an artistic formula the oppression that a person is subjected to in a dehumanized system of national institutions and inhuman world of computers connected to the Web that only gives an illusion of a sense of community.

Artists that produce socially engaged art take on the role of the neglected and disregarded. They perform in the name of those who do not exist in the public space, those whose voice is not heard and who do not have the strength, courage or possibilities to fight for their own rights. Unfortunately, speaking on their behalf does not automatically turn them into visible subjects. In order to come into existence in the public sphere, they have to summon their courage to walk out into the open and begin to speak. The work of these artists can only empower them to speak for themselves. And though it might seem that the Internet is a medium that creates the space for those who did not have the courage to communicate their existence earlier, the real democratic revolution can only take place outside the Web.

\section{References}

Batko, A. (2018). Sukcesizm. Szydełkowanie znacznie rożni się od przywiąywania kochanka do łóżka. magazyn szum.pl. https://magazynszum.pl/sukcesizm-szydelkowanie-znacznie-rozni-sie-od-przywiazywania-kochanka-do-lozka/. 28.04.2018. Bishop, C. (ed.) (2006). Participation. Londyn - Whitechapel: MIT Press.

Bishop, C. (2012). Artificial Hells. Participatory Art and the Politics of Spectatorship. London - New York: Verso.

Bishop, C. (2013). Partycypacja i spektakl. Przeł. P. Juskowiak. "Kultura Współczesna" nr 2, s. 26-36. 
Castells, M. (2012). Networks of outrage and hope-social movements in the Internet age. Chichester: Wiley.

Castells, M. (2013). Sieci oburzenia i nadziei. Ruchy społeczne w erze Internetu. Przeł. O. Siara. Warszawa: Wydawnictwo Naukowe PWN.

Carnevale, F., Kelsey J. (2007). Art of the Possible: an interview with Jacques Rancière. "Artforum" march.

Groys, B., (2016). In the Flow. London: Verso.

Groys, B., (2010). The Weak Universalism. "e-flux" 15. https://www.e-flux.com/journal/15/61294/the-weak-universalism/. 20.04.2018.

Haraway, D. (1985). Cyborgs Manifesto. "Socialist Review" vol. 80, pp. 65-108. Reprint 1991, New York: Routledge.

Kuźmiński, M. (2018). To nie Facebook, to my. "Tygodnik Powszechny" 10.04. https:// www.tygodnikpowszechny.pl/to-nie-facebook-to-my-152622. 20.04.2018.

Rancière, J. (2007). Wyemancypowany widz. Przeł. A. Ostolski. "Krytyka Polityczna" nr 13, pp. 309-319.

Rancière, J. (2008). Na brzegach politycznego. Przeł. I Bojadżijewa, J. Sowa. Kraków: Wydawnictwo Ha! art.

Schjeldahl, P. (2008). Dead-end kids: political art. In: Let's See: Writings on Art from the New Yorker. London: Thames \& Hudson.

Smoleń, J. (2017). Siksa mówi wszystko. Rozmowa z Alex Freiheit. kultura do góry nogami.pl. http://kulturadogorynogami.pl/2017/11/04/siksa-mowi-wszystko-rozmowa-z-alex-freiheit/. 27.04.2018.

Urwanowicz-Rojecka, E. (2015). Od sztuki site-specific po sztuke partycypacyjna. Sztuka zaangażowana - wybrane współczesne teorie i praktyki. "Pogranicze. Studia Społeczne" t. 26. 